\title{
Effect of Sowing Dates and Levels of Nitrogen on Yield Attributes, Protein Content and Economics of Barley (Hordeum vulgare L.)
}

\author{
Borra Chandrasekhar Reddy, Rajesh Singh", Rajana Praveena and S. Ameer Sohail
}

Department of Agronomy, Sam Higginbottom University of Agriculture Technology and Sciences, Allahabad, India

*Corresponding author

\section{A B S T R A C T}

\begin{tabular}{|l|}
\hline K e y w o r d s \\
$\begin{array}{l}\text { Barley, Date of sowing, } \\
\text { Level of nitrogen, Protein } \\
\text { content, Economics, } \\
\text { Yield }\end{array}$ \\
\hline Article Info \\
\hline $\begin{array}{l}\text { Accepted: } \\
\text { 04 July 2018 } \\
\text { Available Online: } \\
\text { 10 August } 2018\end{array}$ \\
\hline
\end{tabular}

\section{Introduction}

Barley (Hordeum vulgare L.) is an important cereal crop of the world. Among cereals, it ranks fourth with respect to area and production after wheat, rice and maize and is a hardy crop grown throughout the temperate, tropical and sub-tropical regions of the world.

It is a rabi cereal crop in India and usually used as food for human beings and feed for animals and poultry birds (Singh et al., 2012). There are evidences to indicate that it is one of the oldest crops known to have been cultivated in India. Barley is quite nutritious cereal. The grains of barley contain 8-10\% protein, good amount of carbohydrates, minerals and

\begin{abstract}
A field experiment was conducted during the rabi season of 2017 in Barley crop (var. "RD2035") at Crop Research Farm, Department of Agronomy, Naini Agricultural Institute, SHUATS, Allahabad (U.P.). The experiment was laid out in Randomized Block Design with 12 treatment combinations, consisting of Four nitrogen levels $(45,60,75$ and $90 \mathrm{~kg} \mathrm{~N} \mathrm{ha}^{-1}$ ) which were on Different Date of sowing viz., $20^{\text {th }}$ Oct, $30^{\text {th }}$ Oct, $10^{\text {th }}$ Nov. The experimental results revealed that Yield parameters viz. grain yield $(5.23 \mathrm{t} / \mathrm{ha})$ and Novign November $+75 \mathrm{Kg}$ Nitrogen $\left.\mathrm{ha}^{-1}\right)$, whereas protein content $(11.52 \%)$ were significantly higher with treatment $\mathrm{T}_{12} 10$ November $+90 \mathrm{Kg}$ Nitrogen $\mathrm{ha}^{-1}$, Economics at gross return $\left(₹ 95042.50 \mathrm{ha}^{-1}\right)$, net return $\left(₹ 63033.90 \mathrm{ha}^{-1}\right)$ and $\mathrm{BC}$ ratio
higher with treatment $\mathrm{T}_{11}\left(10\right.$ November $+75 \mathrm{Kg}^{2}$ Nitrogen ha
\end{abstract}

vitamin. B complex and forms a staple food for many people in India. The dishes like chapati, sattu etc. are prepared from barley flour In addition, the energy rich drinks are also prepared from the malt extracts of barley. In India, about $90 \%$ of the barley produced is used for human consumption, while in USA and European countries most of it is used as cattle feed.

The barley grains make palatable and nutritious livestock feed, the straw is used as forage and green forage either directly fed to the animals or used for making hay and silage. It is a rabi cereal crop is India and usually used as food for human beings and feed for animals and poultry birds (Singh et al., 2012). 
Traditionally considered as a poor man's crop, barley in India is favoured because of its low input requirement and better adaptability to harsh environments, likely drought, salinity/alkalinity and marginal lands. Barley occupied nearly $5.90 \mathrm{lac}^{\mathrm{h}} \mathrm{ha}^{-1}$ area producing nearly 15.05 lac tonnes of grain, with a productivity of $2552 \mathrm{~kg} / \mathrm{ha}$ during 2015-16 in India (Anonymous et al.,2016).

Different doses of nitrogen significantly influenced the grain yield and yield parameters. For the highest grain yield, nitrogen doses of $100 \mathrm{~kg} \mathrm{~N}^{-1}$ were the best when considering nitrogen fertilizer only (Shirazi et al., 2014). Nitrogen (N) is commonly the most limiting nutrient for crop production in the majority of the world's agricultural areas and therefore adoption of good $\mathrm{N}$ management strategies often results in large economic benefits to farmers. Among the most important management practices influencing grain protein content is $\mathrm{N}$ fertilize application rate and timing. Increasing $\mathrm{N}$ fertilizer rates can result in higher grain protein content (Buskiene and Uselis 2008).

Date of sowing is one of the most important factors for higher yield production as it determines the optimum time of sowing of the crop. An optimum time of sowing enhances the efficiency of barley by exploiting growth factors in an effective manner. As dual purpose barley, plant provides green fodder during lean period, the right time of sowing for availability of green fodder for longer time should be optimally utilized and therefore, the effects of various dates of sowing on dual purpose barley are quite remarkable. The staggered sowing is a common practice to obtain high quality green fodder for longer duration. Optimum date of sowing is necessary for maximum possible yield of good quality green fodder because availability of highest nutritive stage for longer duration is desired. However it is essential to follow proper date of sowing to utilize the optimum time of sowing efficiently [Singh et al., (2017)] considering with alone point a field experiment was planned to field out the effect of sowing date and levels, of nitrogen on growth and field of barley.

\section{Materials and Methods}

A field experiment was conducted during the Rabi season of 2017 in barley crop at Crop Research Farm, Department of Agronomy, Naini Agricultural Institute, SHUATS, Allahabad (U.P.). The experiment consisted of and different dates of sowings $20^{\text {th }}$ Oct, $30^{\text {th }}$ Oct, $10^{\text {th }}$ Nov, four nitrogen levels, viz. 45, 60,75 and $90 \mathrm{~kg} \mathrm{~N} \mathrm{ha}{ }^{-1}$ laid out in a Randomized Block Design with twelve treatment combinations, replicated thrice. The soil of the experimental field was sandy loam in texture with $\mathrm{pH} 7.6$, low in organic carbon $0.42 \%$, available $\left.\mathrm{P}(13.50 \mathrm{~kg} \mathrm{ha})^{-1}\right)$ and available K (257.04 $\left.\mathrm{kg} \mathrm{ha}^{-1}\right)$. Nitrogen, Phosphorus and Potassium were applied through urea, DAP (Di Ammonium Phosphate) and muriate of potash, respectively. Half dose of nitrogen was applied as per treatment and full dose of phosphorus, potassium were applied as basal and remaining nitrogen as per treatment was top dressed at tillering stage. The crop received five uniform irrigations. All the growth and yield attributes were recorded using standard procedure and grain yield was calculated at $12 \%$ moisture content.

\section{Results and Discussion}

\section{Effect on Yields and Yield attributes}

The grain yield $\left(5.23 \mathrm{t} \mathrm{ha}^{-1}\right)$ and Straw yield $\left(8.37 \mathrm{t} \mathrm{ha}^{-1}\right)$, was also higher with treatment. $\mathrm{T}_{11}\left(10\right.$ November $+75 \mathrm{Kg}$ Nitrogen $\left.\mathrm{ha}^{-1}\right)$ It might be due to cumulative effect of growth and yield-attributing characters owing to fertilization. 
Table.1 Effect of sowing date and level as of nitrogen on yield barley

\begin{tabular}{|c|c|c|c|c|}
\hline \multirow[t]{2}{*}{ Treatments No. } & \multirow[t]{2}{*}{ Treatments combination } & \multicolumn{2}{|c|}{ Yield } & \multirow{2}{*}{$\begin{array}{c}\text { Harvest index } \\
(\%)\end{array}$} \\
\hline & & Grain yield $\left(\mathrm{t} \mathrm{ha}^{-1}\right)$ & Straw yield (t ha $\left.{ }^{-1}\right)$ & \\
\hline$T_{1}$ & 20October+45 Kg Nitrogen $\mathrm{ha}^{-1}$ & 3.90 & 8.08 & 32.55 \\
\hline $\mathbf{T}_{2}$ & 20 October $+60 \mathrm{Kg}$ Nitrogen $\mathrm{ha}^{-1}$ & 4.79 & 6.30 & 43.19 \\
\hline $\mathbf{T}_{3}$ & 20 October $+75 \mathrm{Kg}$ Nitrogen $\mathrm{ha}^{-1}$ & 4.68 & 8.30 & 36.05 \\
\hline $\mathbf{T}_{4}$ & 20 October+ $90 \mathrm{Kg}$ Nitrogen $\mathrm{ha}^{-1}$ & 4.03 & 7.56 & 32.16 \\
\hline $\mathbf{T}_{5}$ & 30 October $+45 \mathrm{Kg}$ Nitrogen $\mathrm{ha}^{-1}$ & 3.91 & 6.07 & 39.17 \\
\hline$T_{6}$ & 30 October $+60 \mathrm{Kg}$ Nitrogen $\mathrm{ha}^{-1}$ & 4.19 & 4.94 & 45.89 \\
\hline $\mathbf{T}_{7}$ & 30 October $+75 \mathrm{Kg}$ Nitrogen $\mathrm{ha}^{-1}$ & 3.50 & 6.15 & 36.26 \\
\hline$\frac{-1}{\mathbf{T}_{8}}$ & 30 October $+90 \mathrm{Kg}$ Nitrogen $\mathrm{ha}^{-1}$ & 3.99 & 7.53 & 34.63 \\
\hline $\mathbf{T}_{9}$ & 10 November $+45 \mathrm{Kg}$ Nitrogen $\mathrm{ha}^{-1}$ & 4.02 & 7.3 & 35.51 \\
\hline $\mathbf{T}_{10}$ & 10 November + $60 \mathrm{Kg}$ Nitrogen $\mathrm{ha}^{-1}$ & 4.80 & 7.42 & 39.27 \\
\hline$T_{11}$ & 10 November $+75 \mathrm{Kg}$ Nitrogen $\mathrm{ha}^{-1}$ & 5.23 & 8.37 & 42.55 \\
\hline \multirow[t]{4}{*}{$\mathbf{T}_{12}$} & 10 November + $90 \mathrm{Kg}$ Nitrogen $\mathrm{ha}^{-1}$ & 4.43 & 7.89 & 35.95 \\
\hline & F test & S & $\mathrm{S}$ & NS \\
\hline & SEd $( \pm)$ & 0.43 & 0.94 & 4.28 \\
\hline & $\mathrm{CD}(\mathrm{P}=0.05)$ & 0.88 & 1.94 & -- \\
\hline
\end{tabular}

Table.5 Economics effect of date of sowing and nitrogen levels in barley

\begin{tabular}{|c|c|c|c|c|c|}
\hline Treatments No. & Treatments combination & Cost of cultivation(₹) & Gross return (₹) & Net return(₹) & $\mathrm{BC}$ ratio \\
\hline $\mathbf{T}_{1}$ & 20October+45 Kg Nitrogen $\mathrm{ha}^{-1}$ & 31030.30 & 73655.00 & 42624.70 & 2.37 \\
\hline $\mathbf{T}_{2}$ & 20 October $+60 \mathrm{Kg}$ Nitrogen ha ${ }^{-1}$ & 31519.45 & 84945.00 & 53425.55 & 2.70 \\
\hline $\mathbf{T}_{3}$ & 20 October $+75 \mathrm{Kg}$ Nitrogen ha ${ }^{-1}$ & 32008.60 & 86270.00 & 54261.40 & 2.70 \\
\hline $\mathbf{T}_{4}$ & 20 October+ $90 \mathrm{Kg}$ Nitrogen $\mathrm{ha}^{-1}$ & 32497.75 & 74917.50 & 42419.75 & 2.31 \\
\hline $\mathbf{T}_{5}$ & 30 October $+45 \mathrm{Kg}$ Nitrogen $\mathrm{ha}^{-1}$ & 31030.30 & 70692.50 & 39662.20 & 2.28 \\
\hline$T_{6}$ & 30 October $+60 \mathrm{Kg}$ Nitrogen $\mathrm{ha}^{-1}$ & 31519.45 & 73412.50 & 41893.05 & 2.33 \\
\hline $\mathbf{T}_{7}$ & 30 October $+75 \mathrm{Kg}$ Nitrogen $\mathrm{ha}^{-1}$ & 32008.60 & 64402.50 & 32393.90 & 2.01 \\
\hline $\mathbf{T}_{8}$ & 30 October $+90 \mathrm{Kg}$ Nitrogen $\mathrm{ha}^{-1}$ & 32497.75 & 74242.50 & 41744.75 & 2.28 \\
\hline$T_{9}$ & 10 November $+45 \mathrm{Kg}$ Nitrogen $\mathrm{ha}^{-1}$ & 31030.30 & 74317.50 & 43287.20 & 2.39 \\
\hline $\mathbf{T}_{10}$ & 10 November $+60 \mathrm{Kg}$ Nitrogen $\mathrm{ha}^{-1}$ & 31519.45 & 86730.00 & 55210.55 & 2.75 \\
\hline $\mathbf{T}_{11}$ & 10 November $+75 \mathrm{Kg}$ Nitrogen $\mathrm{ha}^{-1}$ & 32008.60 & 95042.50 & 63033.90 & 2.97 \\
\hline $\mathbf{T}_{12}$ & 10 November $+90 \mathrm{Kg}$ Nitrogen $\mathrm{ha}^{-1}$ & 32497.75 & 81612.50 & 49114.75 & 2.51 \\
\hline
\end{tabular}

Respectively when grain were sell at ₹ $12.25 / \mathrm{kg}$ and straw at ₹. $3 / \mathrm{kg}$. 
Table.2 Effect of sowing date and levels of nitrogen on protein (\%)

\begin{tabular}{|l|}
\hline \multicolumn{1}{|c|}{ Treatments No. } \\
\hline $\mathbf{T}_{1}$ \\
\hline $\mathbf{T}_{2}$ \\
\hline $\mathbf{T}_{3}$ \\
\hline $\mathbf{T}_{4}$ \\
\hline $\mathbf{T}_{5}$ \\
\hline $\mathbf{T}_{6}$ \\
\hline $\mathbf{T}_{7}$ \\
\hline $\mathbf{T}_{8}$ \\
\hline $\mathbf{T}_{9}$ \\
\hline $\mathbf{T}_{10}$ \\
\hline $\mathbf{T}_{11}$ \\
\hline $\mathbf{T}_{12}$ \\
\hline
\end{tabular}

\begin{tabular}{|c|c|}
\hline Treatments combination & Protein (\%) \\
\hline 20October+45 Kg Nitrogen ha ${ }^{-1}$ & 8.21 \\
\hline 20 October $+60 \mathrm{Kg}$ Nitrogen ha ${ }^{1}$ & 9.45 \\
\hline 20 October $+75 \mathrm{Kg}$ Nitrogen $\mathrm{ha}^{-1}$ & 10.33 \\
\hline 20 October+ 90Kg Nitrogen $\mathrm{ha}^{-1}$ & 10.83 \\
\hline 30 October $+45 \mathrm{Kg}$ Nitrogen $\mathrm{ha}^{-1}$ & 8.73 \\
\hline 30 October $+60 \mathrm{Kg}$ Nitrogen $\mathrm{ha}^{-1}$ & 9.82 \\
\hline 30 October $+75 \mathrm{Kg}$ Nitrogen $\mathrm{ha}^{-1}$ & 10.72 \\
\hline 30 October +90 Kg Nitrogen ha ${ }^{-1}$ & 11.05 \\
\hline 10 November $+45 \mathrm{Kg}$ Nitrogen $\mathrm{ha}^{-1}$ & 9.66 \\
\hline 10 November $+60 \mathrm{Kg}$ Nitrogen $\mathrm{ha}^{-1}$ & 10.70 \\
\hline 10 November $+75 \mathrm{Kg}$ Nitrogen $\mathrm{ha}^{-1}$ & 11.10 \\
\hline 10 November $+90 \mathrm{Kg}$ Nitrogen $\mathrm{ha}^{-1}$ & 11.52 \\
\hline
\end{tabular}

Table.3 Cost of cultivation effect of date of sowing and nitrogen levels in barley

\begin{tabular}{|c|c|c|c|c|c|}
\hline S. No. & Particulars & Unit & Qty & Rupees (₹ ) & Cost $\left(₹ h^{-1}\right)$ \\
\hline A & Land preparation & & & & \\
\hline 1 & Ploughing & Hours & $3 \mathrm{hr}$ & 660 & 2040 \\
\hline 2 & Disc harrowing & Hours & $3 \mathrm{hr}$ & 690 & 2070 \\
\hline 3 & Layout preparation & Labours & 10 & 300 & 3200 \\
\hline B & Fertilizer application & & & & \\
\hline 1 & Urea $(46 \% \mathrm{~N})$ & $\mathrm{Kg}$ & 70 & 15 & 1050 \\
\hline 2 & DAP & $\mathrm{Kg}$ & 20 & 35 & 700 \\
\hline 3. & MOP & $\mathrm{Kg}$ & 20 & 35 & 700 \\
\hline 3 & Labour for fertilizer application & Labours & 3 & 200 & 600 \\
\hline $\mathrm{C}$ & Seed sowing & & & & \\
\hline 1 & Seed & $\mathrm{Kg}$ & 100 & 35 & 2500 \\
\hline 2 & Labour per sowing & Labours & 8 & 200 & 1600 \\
\hline D & Irrigation & & & & \\
\hline 1 & Tube well charge & Hours & 8 & 100 & 800 \\
\hline 2 & Labour per irrigation & Labours & 3 & 300 & 900 \\
\hline $\mathbf{E}$ & Inter-culture & & & & \\
\hline 1 & Thinning and Weeding & Labours & 10 & 200 & 2000 \\
\hline $\mathbf{F}$ & Plant protection & & & & \\
\hline 1 & Choloroparopase & lit & 3 & 350 & 1150 \\
\hline 2 & Labour per spray & Labours & 4 & 200 & 800 \\
\hline G & Harvesting & & & & \\
\hline 1 & Harvesting & Labours & 15 & 200 & 3000 \\
\hline 2 & Threshing & Labours & 14 & 200 & 2800 \\
\hline $\mathbf{H}$ & Rental value of land & Months & 4 & 800 & 3200 \\
\hline I & Supervision charges & Months & 4 & 900 & 3400 \\
\hline & Total cost of cultivation $\left(\mathrm{ha}^{-1}\right)$ & & & & 32010 \\
\hline
\end{tabular}


Table.4 Variable cost for barley

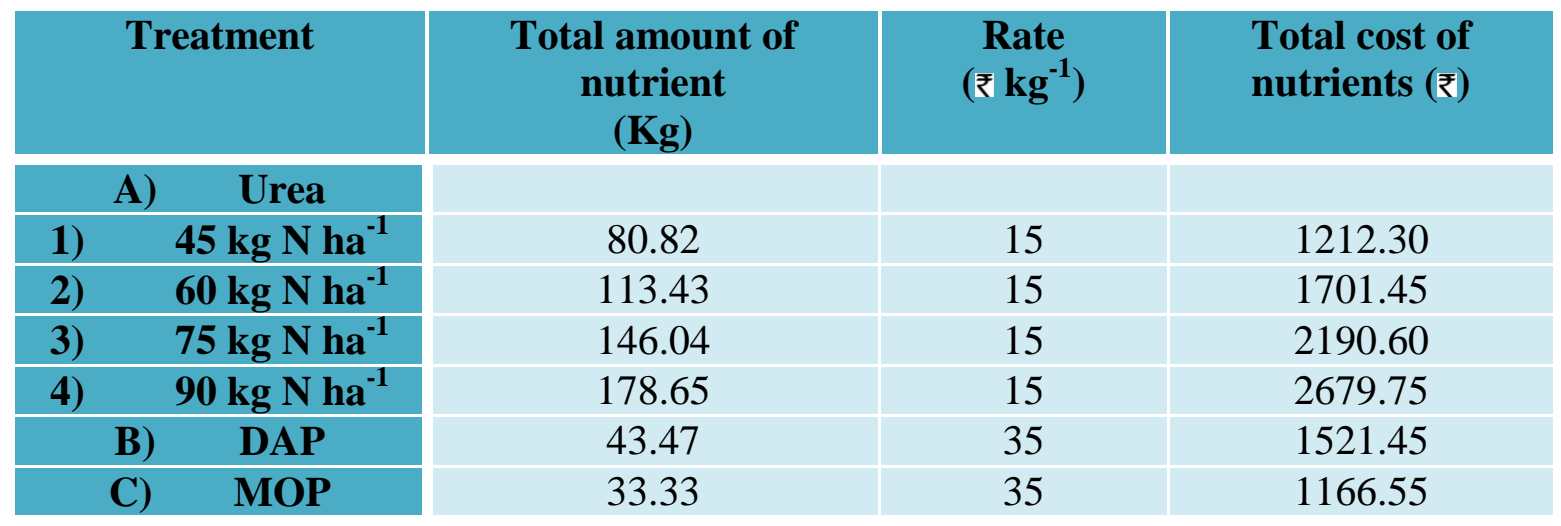

Greater availability of metabolites (photosynthates) and nutrients to developing reproductive structures seems to have resulted in increase in all the yield-attributing characters which ultimately improved the yield of the crop Singh et al., (2010). Similar findings were also reported by Meena et al., (2012) and Singh et al., (2013).

\section{Effect on protein content and economics of barley}

Among the treatments $T_{12}(10$ November +90 $\mathrm{Kg} \quad \mathrm{N}$ ha $^{-1}$ ).produced significantly higher protein content, i.e. at (11.52), Economics at gross return (₹ 95042.50 ha ${ }^{-1}$ ), net return (₹63033.90 ha ${ }^{-1}$ ) and BC ratio (₹ 2.97) were significantly higher with treatment $\mathrm{T}_{11}(10$ November $+75 \mathrm{Kg}$ Nitrogen $\mathrm{ha}^{-1}$ ). Taalab et al., (2015) Grain protein content was found to be significantly influenced by $\mathrm{N}$ application rate, and $\mathrm{N}$ time of application. Grain protein content under different $\mathrm{N}$ application rates ranged from 10.83 to $13.68 \%$. Over all, grain protein content was found to increase with increasing $\mathrm{N}$ application rate. The highest grain protein content $(13.68 \%)$ was obtained at the highest $\mathrm{N}$ rate $(100 \mathrm{~kg} \mathrm{~N}$ acre-1) under four splits application of nitrogen. Similar findings were also reported by Brian et al., (2007). Paniya et al., (2015) at observed higher net return (₹ 65800.55) and benefit cost ratio (4.01) when $\mathrm{N}$ was applied at $90 \mathrm{~kg}$ $\mathrm{ha}^{-1}$ to barley. Similar findings were also reported by Katiyar and Uttam (2007) in barley.

On the basis of above findings it can be concluded that the grain yield $\left(5.23 \mathrm{t} \mathrm{ha}^{-1}\right)$, straw yield $\left(8.37 \mathrm{t} \mathrm{ha}^{-1}\right)$, yield attributes and Economics BC ratio (₹ 2.97) were found to be the best with treatment $\mathrm{T}_{11}$ (10 November + $75 \mathrm{~kg}$ Nitrogen $\mathrm{ha}^{-1}$ ). These findings are based on 1 season; trial therefore, further trials may be required for considering it for recommendation.

\section{References}

Anonymous et al., 2016: Progress Report of All India Coordinated Wheat and Barley Improvement project 2015-16. Director's Report, G. P. Singh (ed.). ICAR-Indian Institute of Wheat and Barley Research, Karnal, India. p. 96.

Brian, N. O., Mohamed, M., Joel, K. R. 2007. Seeding rate and nitrogen management effects on spring wheat yield and yield components. Am. J. Agron. 99, 16151621.

Buskiene L. and Uselis N. 2008. The influence of nitrogen and potassium fertilizers on the growth and yield of raspberries cv. Polana. J. Agron. Res. 6(1): 27-35. 
Jasvinder Singh1, S.S. Mahal and Avtar Singh. (2013). Productivity and quality of malt barley (Hordeum vulgare) as affected by sowing date, rate and stage of nitrogen application. Indian Journal of Agronomy 58 (1): 72-80 (March 2013).

Katiyar, A.K. and Uttam, S.K. (2007).Effect of fertility levels and weed control measures on growth, yield attributes and yield of barley (Hordeum vulgare L.) under rainfed condition. Bhartiya Krishi Anusandhan Patrika, 22: 324-26.2005.

Magan Singh, Avinash, Chauhan, Rakesh Kumar, Deepa Joshi, Pooja, Gupta, Soni and V.K. Meena. (2017). Dual purpose barley as affected by date of sowing, varieties and stage of harvesting-A review. Agricultural Reviews, 38 (2) 2017: 159-164.

Meena, L.R., Mann, J.S and Meena, S.L. (2012). Effect of levels and mode of nitrogen application on dual purpose barley (Hordeum vulgare L.) under semi-arid condition. Indian Journal of Agronomy 57(2): 168-170.

Puniya, M.M., Yadav, S.S. and Shivran, A.C. (2015). Productivity, profitability and nitrogen-use efficiency of barley (Hordeum vulgare) as influenced by weed management and nitrogen fertilization under hot semi-arid ecologies of Rajasthan. Indian Journal of Agronomy 60(4): 564-569.

Sarwar, N., Maqsood, K., Mubeen, M., Shehjad, M., Bhuller, M.S., Qamar, R. and Akba N 2010. Effect of different level of irrigation on yield and yield component of wheat cultivars. Pakistan Journal of Agricultural Sciences. 47(3): 371-374.

Shirazi, S.M., Zulkifli, Y., Zardari, N.H. \& Ismail, Z. 2014. Effect of irrigation regimes and nitrogen levels on the growth and yield of barley. Advances in Agriculture. 5: 1-6.

Singh A., Agrawal M., Marshall F.M. (2010): The role of organic vs. inorganic fertilizers in reducing phytoavailability of heavy metals in a wastewaterirrigated area. Ecological Engineering, 36: 1733-1740.

Singh, B., Dhaka, A.K. and Kumar, M. 2016. Performance of dual purpose barley varieties under different nitrogen application schedules. Forage Research. 41(4): 246-248.

Singh, J., Mahal, S.S. and Manhas, S.S. (2012). Effect of sowing methods, nitrogen levels and irrigation scheduling on yield and quality of malt barley (Hordeum vulgare L.) Indian Journal of Agrnomy, 57(3): 259-264.

Taalab, A. S., Safaa, A. Mahmoud and Hanan, S. Siam (2015) Implication of Rate and Time of nitrogen application on Yield and Nitrogen Use Efficiency of Barley in Sandy Soil International Journal of ChemTech Research CODEN (USA): IJCRGG ISSN: 09744290 Vol.8, No.6, pp 412-422, 2015.

\section{How to cite this article:}

Borra Chandrasekhar Reddy, Rajesh Singh, Rajana Praveena and Ameer Sohail, S. 2018. Effect of Sowing Dates and Levels of Nitrogen on Yield Attributes, Protein Content and Economics of Barley (Hordeum vulgare L.). Int.J.Curr.Microbiol.App.Sci. 7(08): 435-440. doi: https://doi.org/10.20546/ijcmas.2018.708.049 